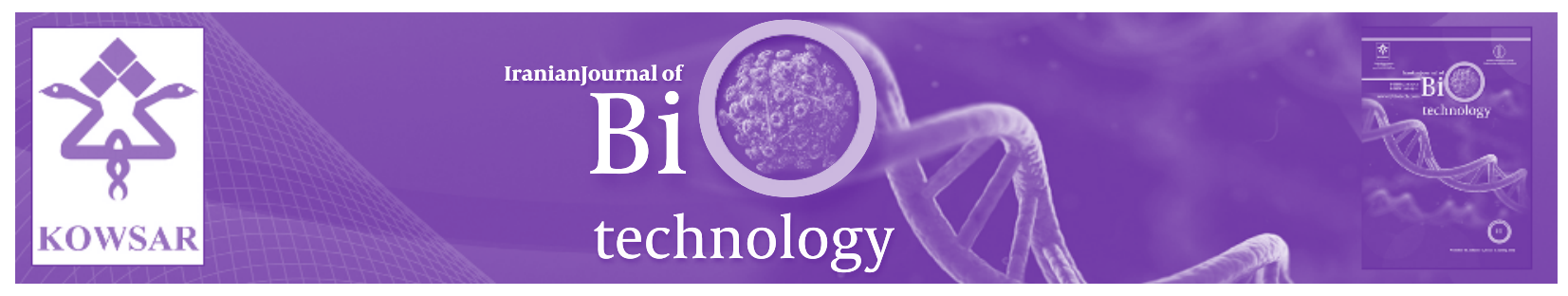

\title{
Sugarcane (NCo310) Transient Transformation Using uidA Reporter Gene
}

\author{
Soheila Matroodi ${ }^{1,2}$, Mostafa Motallebi ${ }^{1{ }^{1, *},}$, Mohammadreza Zamani ${ }^{1}$, Amir Mousavi ${ }^{1}$, Dary- \\ oush Davoodi ${ }^{3}$, Zahra Moghaddassi-Jahromi ${ }^{1}$ \\ ${ }^{1}$ National Institute of Genetic Engineering and Biotechnology, Tehran, IR Iran \\ ${ }^{2}$ Faculty of Marine Sciences, Khorramshahr Marine Sciences and Technology University, Khorramshahr, IR Iran \\ ${ }^{3}$ Agricultural Biotechnology Research Institute of Iran, Tehran, IR Iran \\ *Corresponding author: Mostafa Motallebi, National Institute of Genetic Engineering and Biotechnology (NIGEB), P.O. Box 149651/161, Tehran, Iran, Tel/Fax: \\ +98-2144580363, E-mail: motalebi@nigeb.ac.ir.
}

\begin{abstract}
A B S T R A C T
Background: Sugarcane is a monocotyledonous crop that is cultivated in the tropical and subtropical regions of the world. One of the most important criteria, influencing the efficiency of the sugarcane transformation is known to be related to physical and biological factors during the transformation procedure.

Objectives: The objective of this research was to study the response of callus induction and embryogenic callus production and to identify the major parameters controlling DNA delivery by particle bombardment into sugarcane (Saccharum officinarum L.) cv. NCo310.

Materials and Methods: For callus induction and embryogenic callus production, leaf base segments were subjected to in vitro culture medium supplemented with two plant growth regulators (2,4-D and Dicamba). Results showed that 1 mg.L-12,4-D was significantly influential in callus induction and embryogenic callus production. Considering both physical and biological factors, the efficiency of DNA (uidA gene) delivery was assessed by scoring transient GUS (gene ( $\beta$-glucuronidase)) expression in bombarded tissues.

Results: The highest transient GUS expression was obtained when callus was bombarded with the construct harboring rice Act1 promoter, and having $9 \mathrm{~cm}$ target distance, $25 \mathrm{inHg}$ vacuum pressure, $1 \mu \mathrm{m}$ gold particles, $12.5 \mu \mathrm{g}$ DNA per bombardment and one day pre-culture prior to the bombardment.

Conclusions: A bombardment procedure suitable for elite sugarcane varieties was developed, which allowed high-efficiency DNA delivery combined with reduced damage to target tissues.
\end{abstract}

Keywords: Sugarcane; Callus Induction; Embryogenic; DNA Delivery; Particle Bombardment; Transient GUS Expression

Copyright () 2013, National Institute of Genetic Engineering and Biotechnology; Published by NewPub.

\section{Background}

Sugarcane belongs to the grass family (Poaceae), which is cultivated primarily for its ability to store high concentrations of sugar in the internodes of its stem (1). Modern sugarcane varieties are complex interspecific hybrids primarily involving crosses between the species S. officinarum L. and S. spontaneum L. that have been produced through intensive selective breeding (2). Varieties of sugarcane are highly heterogeneous and are generally

Article type: Research Article; Received: 12 Aug 2012; Revised: 16 Feb 2013; Accepted: 11 Mar 2013; Epub: 15 May 2013, Ppub: June 2013

Implication for health policy/practice/research/medical education:

This study has implication on plant biotechnology researches.

PPlease cite this paper as:

Matroodi S, Motallebi M, Zamani MR, Mousavi A, Davoodi D, Moghaddassi-Jahromi Z. Sugarcane (NCo310) Transient Transformation Using uidA Reporter Gene. Iran J Biotech. 2013:11(2): 89-95.

Copyright (C) 2013, National Institute of Genetic Engineering and Biotechnology; Published by NewPub.

This is an Open Access article distributed under the terms of the Creative Commons Attribution License (http://creativecommons.org/licenses/by/3.0), which permits unrestricted use, distribution, and reproduction in any medium, provided the original work is properly cited. 
multiplied vegetatively by stem cutting (3). An advantage of tissue culture amongst many other approaches is the production of high quality and uniform planting material that can be multiplied under disease-free conditions (4). Tissue culture techniques have been widely used in Saccharum spp. for various purposes. Meristem tip or shoot tip cultures (using apical meristems) have been used as a tool to produce virus-free plants (5). Genotype is another important factor influencing the efficiency of callus production and plant regeneration capacity (6). Burner (7) and Gandonou et al., (8) reported that genotype highly affects callusing responses in sugarcane. Somatic embryogenesis offers an efficient regeneration system for the production of a large number of uniform plants within a short period. Somatic embryogenesis in sugarcane has been reported using immature inflorescences (9), apical meristems (10) and young leaves (11). Biolistic mediated transformation is preferred over Agrobacterium-mediated transformation as it does not require construction of a specialized vector. Also, the advantage of biolistic technology for direct gene transfer into plant cell/tissues has facilitated plant transformation on monocots such as maize (12), wheat (13), rice (14), barley (15), palm date (16) and oil palm (17). The efficiency of biolistic transformation depends on certain physical and biological parameters (18).

\section{Objectives}

In the present study, sugarcane cv. NCo310, which is considered as a widely used cultivar was evaluated for callus induction, embryogenesis and transformation via particle bombardment. Successful transformation was complemented with the desired genes and putative transgenic plants could be selected precisely.

\section{Materials and Methods}

All chemicals were purchased from Merck (Germany), unless otherwise stated.

\subsection{Plant Materials and Explants Preparation}

The sugarcane (S. officinarum L.) cv. NCo310 plants were obtained from Iranian Sugarcane Research and Training Institute, and used as the mother plant. Different treatments were used for sterilization of the explants. The 5 $\mathrm{mm}$ of the stem apex were surface disinfected with 70\% ethanol followed by a subsequent hot water $\left(50^{\circ} \mathrm{C}\right)$ treatment for $2 \mathrm{~h}$ and submerged in varying concentrations $(0.2,0.5$, and $0.7 \%)$ of mercuric chloride $(\mathrm{HgCl} 2)$ for 10 min followed by three rinses with sterile $\mathrm{dH} 2 \mathrm{O}(10 \mathrm{~min}$ each).

\subsection{Culture Media and Conditions}

The MS medium (19) supplemented with different concentrations of 2, 4 Dichlorophenoxyacetic acid (M1:1 mg.L ${ }^{1}$; M2: 2 mg.L ${ }^{-1}$; M3:3 mg.L L $^{-1}$; M 4 mg.L L $^{-1}$ ) and Dicamba (M5: 4 mg. $\left.\mathrm{L}^{-1} ; \mathrm{M} 6: 6 \mathrm{mg} . \mathrm{L}^{-1}\right)$ and 30 g. $\mathrm{L}^{-1}$ sucrose was used for callus induction. The pH was adjusted to 5.8 with $1 \mathrm{~N} \mathrm{NaOH}$ and all media were solidified with 8 g.L. ${ }^{-1}$ agar before autoclaving for $20 \mathrm{~min}$ at $121^{\circ} \mathrm{C}$. Five explants per Petri dish were cultivated and cultures were kept in dark at $28^{\circ} \mathrm{C}$ for one month. Callus induction percentage was determined after two weeks. After one month of culture, the number of embryogenic calli was recorded. Three Petri dishes were bombarded for each treatment. Histochemical GUS assays were conducted $24 \mathrm{~h}$ after bombardment.

\subsection{Plasmid DNA and Microparticle Preparation}

The plasmids used for the transient expression experiments are listed in Table 1 . Gold ( $1 \mu \mathrm{m}$ in diameter) or tungsten particles ( $1.1 \mu \mathrm{m}$ in diameter; BioRad, USA) were coated with plasmid DNA following the protocol accompanied by the biolistic PDS-1000/He with some modifications (BioRad, USA). A volume of $50 \mu \mathrm{L}$ of particle solution (60 mg. $\mathrm{L}^{-1}$ prepared in 50\% glycerol), together with $50 \mu \mathrm{L}$ $\mathrm{CaCl} 2(2.5 \mathrm{M})$ and $20 \mu \mathrm{L}$ spermidine $(0.1 \mathrm{M})$ were added to $1 \mu \mathrm{g}$ of DNA one by one while vigorously vortexed. The microcarriers were allowed to settle for $1 \mathrm{~min}$ and pelleted by spinning for $2 \mathrm{~s}$ in a microfuge. After discarding the supernatant, the pellet was washed twice by $140 \mu \mathrm{L}$ of $70 \%$ ethanol and $140 \mu \mathrm{L}$ of $100 \%$ ethanol. After adding $48 \mu \mathrm{L}$ of $100 \%$ ethanol and resuspension of pellet by vortex, $6 \mu \mathrm{L}$ of the DNA-coated microcarrier suspension was loaded into the center of a macrocarrier, air dried and used for bombardment. Unless otherwise stated, particle bombardment was performed with a single bombardment and $1 \mu \mathrm{g}$ DNA was used. The range of variations from the standard procedure is listed in Table 2. Bombardment parameters were tested independently, maintaining other conditions as in the standard procedure.

\begin{tabular}{|c|c|c|c|c|}
\hline Plasmid Type & GUS Gene & Promoter Type & Plasmid Size, kb & References \\
\hline pBI121 & + & CaMV $35 S^{a}$ & 14.7 & Clontech, USA \\
\hline pBI221 & + & CaMV $35 S^{\mathrm{a}}$ & 5.6 & Clontech, USA \\
\hline pAct1-D & + & $\mathrm{Act}^{\mathrm{a}}$ & 7.5 & McElroyet al.(20) \\
\hline pUBI121 & + & $\mathrm{Ubi}^{\mathrm{a}}$ & 16.7 & In this study \\
\hline
\end{tabular}

\footnotetext{
a Abbreviations: CaMV 35S: cauliflower mosaic virus 35S; Act: actin; Ubi: ubiquitin
} 


\begin{tabular}{ll}
\hline Table 2. Particle Bombardment Parameters Tested Independently for Their Effect on DNA Deliveryin to Sugarcane Callus \\
\hline Bombardment Parameters & Conditions Tested \\
\hline Macrocarrier type & gold and tungsten \\
\hline Chamber vacuum pressure, inHg & 23 and 25 \\
\hline Distance from macrocarrier to target tissue, $\mathbf{c m}$ & $6,9,12$ \\
\hline Number of bombardments & single and double \\
\hline Plasmid type & pBI121, pBI221, pAct1-D, pUBI121 \\
\hline DNA concentration, $\mu$ g & $0.5,1,2.5,5,12.5,25$ \\
\hline Osmoticum type & manitol, sorbitol, manitol+sorbitol \\
\hline
\end{tabular}

\subsection{Histochemical GUS Assay and Assessment of Transient Expression}

Bombarded calli remained on the same plates for $24 \mathrm{~h}$ before assay. GUS expression analysis was performed by adding $1 \mathrm{ml}$ of X-gluc staining solution to transformed calli, followed by incubation for $24 \mathrm{~h}$ at $37^{\circ} \mathrm{C}$, as described by Jefferson et al. (21) with some modifications. The staining solution consisted of phosphate buffer $(500 \mathrm{mM})$, EDTA $(10 \mathrm{mM})$, Triton-X100 (0.1\%) and X-gluc (100 mM) dissolved in dimethylformamide (DMF). The $\mathrm{pH}$ of the final solution was adjusted to 7.5. Transient GUS activity was recorded as the number of blue spots in each treatment under a Stemi 2000-C binocular microscope (Zeiss, Germany).

\subsection{Statistical Analyses}

Samples (Petri dishes) in an experiment were completely randomized with 3 replicates. Statistical analysis of data was conducted using one-way ANOVA by the PROCGLM program of SAS (22). Analysis of variance was performed for each treatment. Means were separated at the $5 \%$ probability level with the Tukey test when a significant F ratio occurred $(\mathrm{P}<0.05)$.

\section{Results}

The explants were treated with different aseptic conditions before transfer to the callus induction medium. The treatment of the explants with hot water $\left(50{ }^{\circ} \mathrm{C}\right)$ for $2 \mathrm{~h}$ before incubation in different concentrations of mercuric chloride resulted in an efficient surface disinfection. It was also observed that the lowest percent of subsequent contaminations could be obtained when the leaf sheath explants were treated with $0.7 \% \mathrm{HgCl} 2$ for $10 \mathrm{~min}$ (Figure 1). Each explant showed different responses on different combinations of growth regulators. The optimum conditions for the generation of embryogenic calli in NCo310 cultivar were determined. Effects of three concentrations of 2,4-D (1 mg. $\mathrm{L}^{-1} ; 2$ mg. $\mathrm{L}^{-1}$ and 4 mg. $\left.\mathrm{L}^{-1}\right)$ and two concentrations of Dicamba ( $4 \mathrm{mg} . \mathrm{L}^{-1}$ and $6 \mathrm{mg} . \mathrm{L}^{-1}$ ) on the production of callus and embryogenic calli (yellow and compact) were investigated. Results showed that $1 \mathrm{mg}$..-12,4-D had significant effects on the total number of explants, which produced embryogenic callus compared to other concentrations of 2,4-D and Dicamba (Figure $2 A$ and $2 B$ ). Most of the explants cultured on callus induction medium exhibited swelling after 5 - 7 days followed by callusing within the next two weeks and embryogenesis (the yellow and compact embryogenic calli) after one month (Figure 3). These embryonic calli were selected as target tissues to establish a transformation system for sugarcane cultivar NCo310 by optimizing the physical and biological parameters affecting transient expression of uidA gene, defined by the number of blue spots (Figure 4).

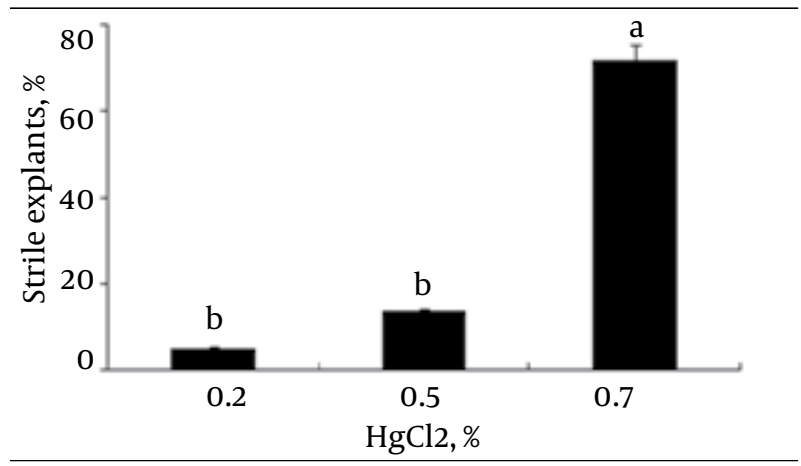

Figure 1. Effect of \% $\mathrm{HgCl} 2$ on Explant Sterilization

\subsection{Particle Bombardment Parameters}

\subsubsection{Effect of Promoter Type}

Comparison of transient expression level of the GUS gene under control of different promoters in sugarcane calli was performed. It was interesting to check the effectiveness of two monocot- derived promoters (Act1 and Ubi) and CaMV 35S promoter in sugarcane calli. For this reason, four plasmids with three different promoters (pBI221 and pBI121 harboring CaMV 35S, pAct1-D harboring rice Act1, and pUBI121 harboring rice ubiquitin promoter) carrying the GUS reporter gene were bombarded after precipitating with gold particles. Among the four constructs tested, pAct1-D and pUBI121 vectors showed significant increase in GUS expression with $69 \pm 8$ and $38 \pm 3$ blue spots, respec- 
tively. Whereas, no significant difference was observed between the two other plasmids, pBI221 and pBI121 with $11 \pm 2$ and $5 \pm 4$ blue spots, respectively (Figure $5 \mathrm{~A}$ ).
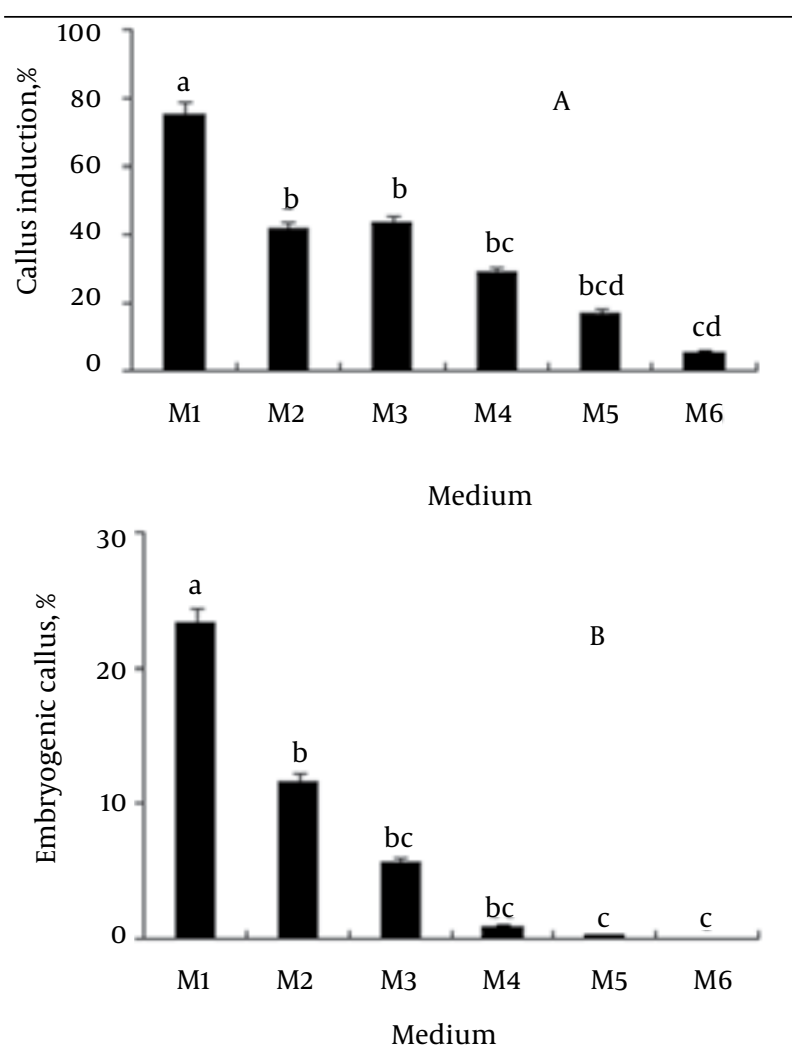

Figure 2. Effect of Different Concentrations of 2,4-D(M1,1 mg.L-1; M2,2 mg.L

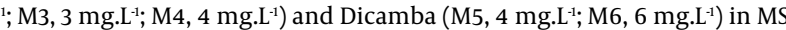
medium on Callus and Embryogenic Callus Induction; Means Within Column Followed by the Same Letter are not Significantly Different $(\mathrm{P}>0.05)$

Figure 3. Embryogenic Callus Induced From Leaf Explants of Sugarcane cv. NCo310
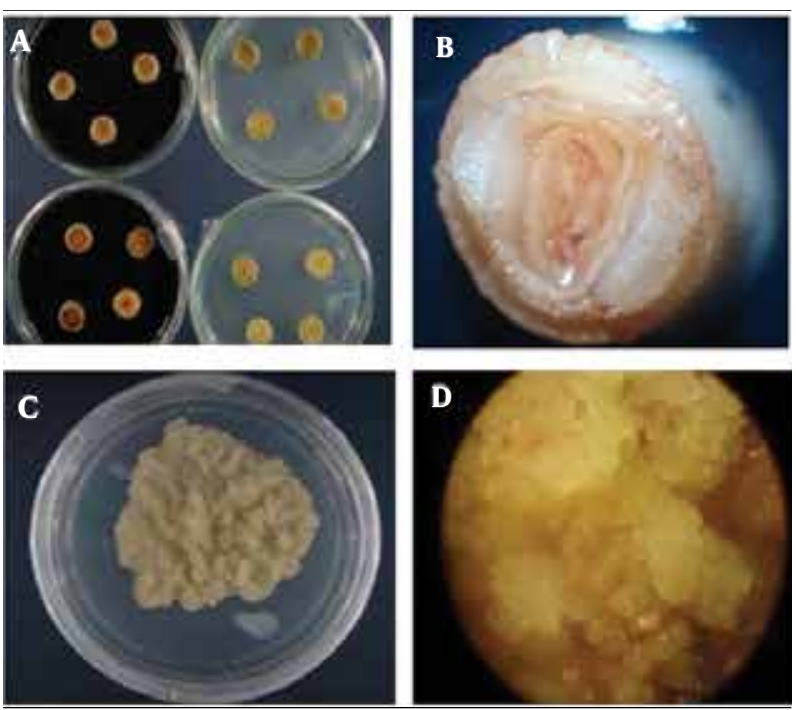

A, Explants adaptation; B, Callus induction; C, Callus propagation; D, Embryogenic callus developed after four weeks of culture in the MS medium
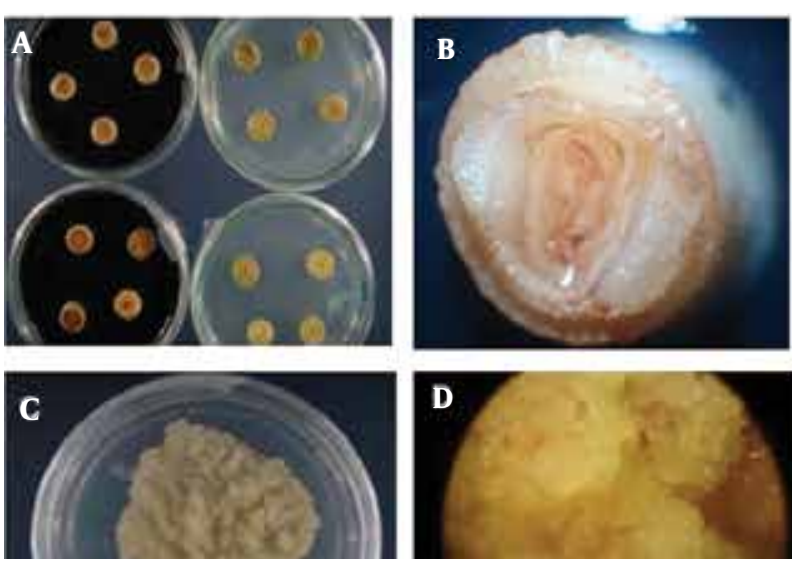

Figure 4. Transient GUS Expression Pattern Inembryogenic Calli of Sugarcane Bombarded With the Construct Carrying the Ubi Promoter

\subsubsection{Osmotic Conditioning of Callus}

Callus culture on MS medium supplemented with 2 mg.L ${ }^{-1}$ 2,4-D and 0.2 M sorbitol + 0.2 M manitol significantly improved transient GUS expression (56 \pm 17 ) in comparison with calli cultured on $0.4 \mathrm{M}$ sorbitol (23 \pm 3 ) and 0.4 M manitol ( $22 \pm 7$ ) (Figure $5 \mathrm{~B}$ ). Osmotic treatments of embryogenic calli were used four hours before bombardment and one day after bombardment followed by histochemical GUS staining

\subsubsection{Quantitation of DNA and Particle Type}

To evaluate the effect of plasmid DNA concentration for efficient coating of the microcarrier, we used different concentrations of pAct1-D at 0.5, 2.5, 12.5 and $25 \mu \mathrm{g}$ per shot. It was found that $12.5 \mu \mathrm{g}$ DNA per shot gave the highest transient GUS expression (702 \pm 43 ). Lower concentration of DNA $(0.5 \mu \mathrm{g})$ was found to give lower blue foci $(43 \pm 3)$. This observation could be due to the insufficient amount of DNA in proportion to the microparticles for delivery. The average numbers of blue foci for other concentrations, 2.5 and $25 \mu \mathrm{g}$ were $109 \pm 4$ and $232 \pm 35$, respectively (Figure $5 C)$. Gold $(1 \mu \mathrm{m})$ particles showed significantly higher number of the blue foci per shot $(205 \pm$ 23) than tungsten $(1.1 \mu \mathrm{m})$ particles $(48 \pm 10)$ (Figure 6A).

\subsubsection{Effect of Times of Bombardments and Cham- ber Vacuum Pressure}

There was no significant difference in GUS expression carrying out single $(105 \pm 24)$ or multiple (two) bombardments $(148.8 \pm 9)$ on sugarcane callus (Figure $6 B$ ).

Also we found that DNA delivery at 25 Inch of Mercury (inHg) significantly increased the efficiency of transient GUS expression ( $422 \pm 26)$ in comparison with lower vacuum pressure (23 inHg) resulting in $215 \pm 19$ blue spots (Figure 6C). 
Figure 5. Effect of Biological Parameters on Transient expression of the GUS Gene in Bombarded Sugarcane Embryogenic Calli
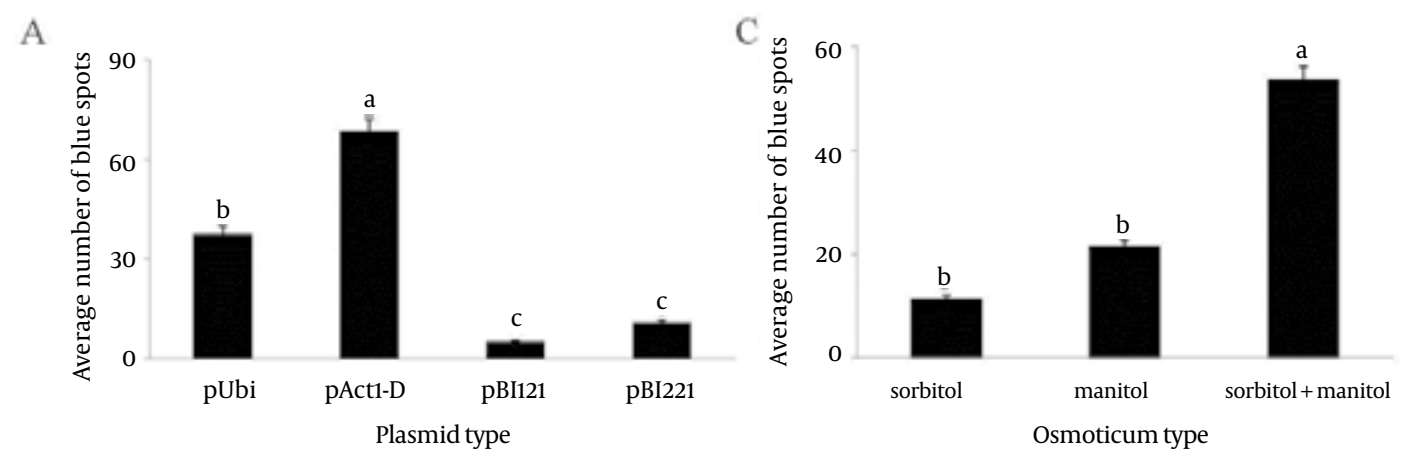

$$
\text { B }
$$

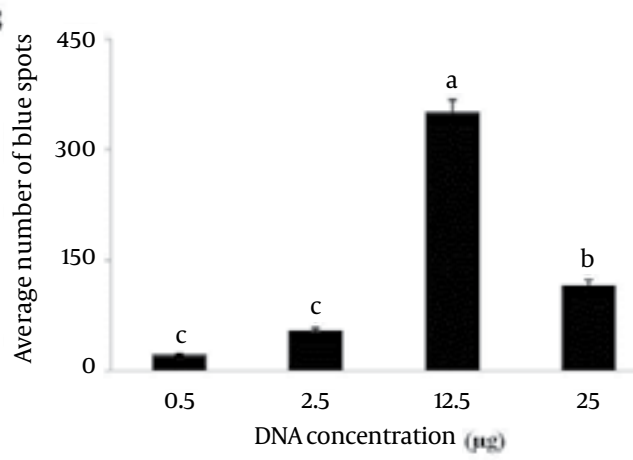

A, Plasmid type; B, Osmoticum type; and C, DNA quantity per shot. Data represent the Mean \pm SD determined from at least three replicates and were analyzed using one-way ANOVA (PROC-GLM program of SAS). Different letters indicate significant differences at the level of $\mathrm{P}<0.05$ within a parameter.

Figure 6. Effect of Physical Parameters on Transient Expression of the GUS Gene in Bombarded Sugarcane Embryogenic Cali

A

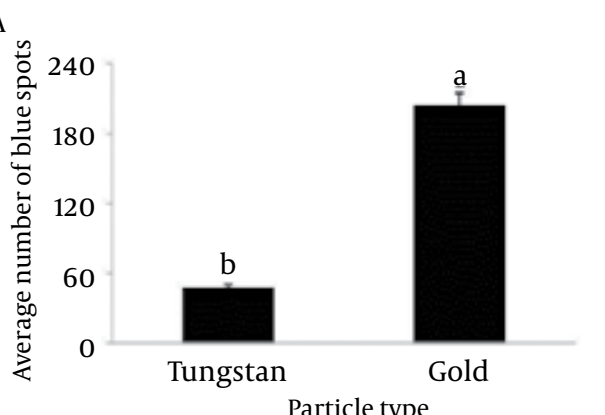

C

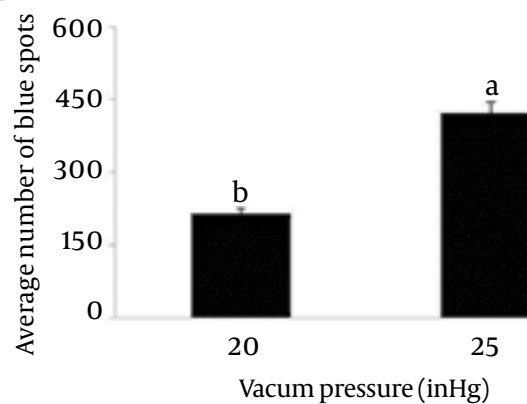

B

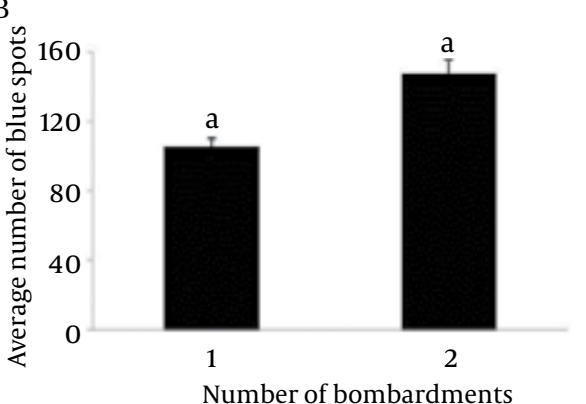

$\mathrm{D}$

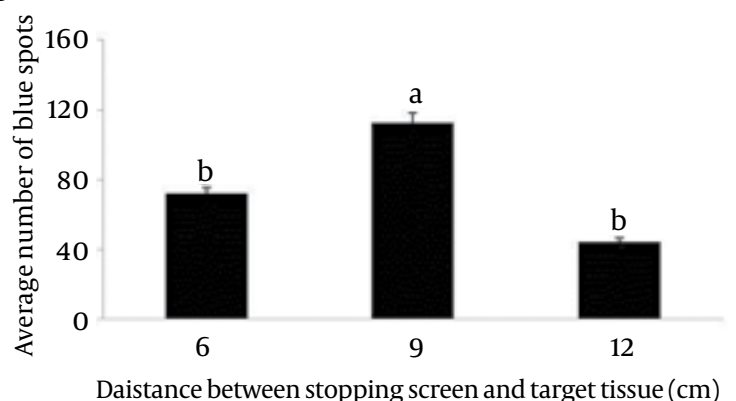

A, particle type; B, bombardment number; C, vacuum pressure and D) distance from stopping screen to target tissue. Data represent the Mean \pm SD determined from at least three replicates and were analyzed using one-way ANOVA (PROC-GLM program of SAS). Different letters indicate significant differences at the level of $\mathrm{P}<0.05$ within a parameter. 


\subsubsection{Selection of Appropriate Distance From Microcar- rier Launches Assembly to the Target Tissue}

There are three adjustable distances that influence the delivery of particles using the PDS-1000/He system, namely, gap distance (between rupture disk and macrocarrier), macrocarrier travel distance (between macrocarrier and stopping screen) and the target distance (between stopping screen and target plate). When the distance between calli and macro carrier was $9 \mathrm{~cm}$, a significantly higher number of blue spots $(112 \pm 29)$ were detected in comparison with 6 and $12 \mathrm{~cm}$ distances which showed $71 \pm 5$ and $44 \pm 7$ blue spots, respectively (Figure $6 D$ ).

\section{Discussion}

The commercial sugarcane is not considered as pure $S$. officinarum but a hybrid species; complex polyploid with a large number of chromosomes. This does not provide a reliable system for genetic manipulation through conventional means. There are a few reports on successful genetic transformation of the sugarcane $(23,24)$. One of the most important criteria, influencing the efficiency of the transformation is known to be related to physical and biological factors during the transformation procedure. At present, transformation of sugarcane is mostly achieved by microprojectile bombardment (25). In this study, we have tried to determine which combination of physical and biological parameters gives the highest transient expression of the introduced uidA reporter gene in NCo310 sugarcane. The expression level of the introduced gene highly depends on the strength of the promoter that controls transcription of the transgene. For this purpose, transient expression of the uidA reporter gene was evaluated under the control of a number of promoters. Although the CaMV $35 \mathrm{~S}$ promoter has been shown to be active in most tissues of several plant species (26), in this research it was found to be the weakest of the promoters tested in sugarcane. While differences in transient gene expression level were observed among the monocot promoters, the highest activity was obtained with the Act1 promoter, which is in agreement with previous reports on the Act1-D promoter activity in other monocots such as date palm (16) and rice (27). In conclusion, the histochemical staining results indicated that the rice Act1 promoter is preferred for stable expression of foreign genes in sugarcane callus. The distance from the microprojectile launch site to the biological target can affect the velocity of microprojectiles and consequently transformation rates $(16,28)$. Our results showed that $9 \mathrm{~cm}$ is the most effective distance in particle bombardment of NCo310 by pAct1-D harboring plasmid. To improve the coverage of targeted areas, multiple bombardments were used. Although this can increase the efficiency of transformation when the primary delivery is not efficient, yet at the same time, it may result in an increase in the damage done to the target tissues (29) and thus are undesirable for stable transformation. In cassava (30), banana (31) and Brazilian maize inbred lines (28), double bombardment was shown to be more effective in transient expression than single. But our results showed no significant difference between single and double bombardment which is in agreement with the reported results on oil palm (32), and date palm (16). Non-metabolisable osmotica such as mannitol, sorbitol and PEG or combinations of these are commonly used to minimize cytoplasm leakage from target cells $(33,34)$. We found that the combination of mannitol and sorbitol significantly increased the average numbers of blue foci. Our results showed a significant increase in GUS expression when a gold particle was used as a microcarrier. Gold microcarrier is biologically inert, non toxic and uniform in size and shape. It generates better performance in particle bombardment than tungsten that could be potentially harmful to some cell types, via acidification and degradation of DNA bonds (18). Vacuum pressure has an important role in the acceleration of the microcarrier from stopping screen to the target tissue (32). A partial vacuum is generally applied in the bombardment chamber because the residual gas in the chamber could cause rubbing forces inducing a deceleration of particles (18). In our research $25 \mathrm{inHg}$ significantly increased the efficiency of transient GUS expression. Lower vacuum pressures did not allow particles to reach the target tissue. This is in agreement with previous results obtained on Catharanthus roseus cells and wheat tissues (25). Increasing the concentration of DNA which was shown to have no significant effect on transgene expression, could instead be considered uneconomical and cause more particle aggregations resulting in poor efficiency of cell penetration and cell injury (34). Increasing the concentration of DNA from $2.5 \mu \mathrm{g}$ up to $25 \mu \mathrm{g}$ in bombarded calli of date palm increased the average number of blue foci but with no significant difference among them (16). This is in agreement with our data showing that $12.5 \mu \mathrm{g}$ DNA per shot gave the highest transient GUS expression. In conclusion, we provided in this work an optimized protocol for embryogenic callus production and biolistic-mediated transient transformation of sugarcane callus, which allows one to obtain a high number of transformed cells. Such an approach will be very useful to introduce agronomical important genes into tropical sugarcane lines.

\section{Acknowledgements}

This research was financially supported by the National Institute of Genetic Engineering and Biotechnology. We kindly appreciate the \&quot;Iranian Research and Training Sugarcane Institute, Ahwaz, Iran for providing the plant materials.

\section{Authors' Contribution}

Mostafa Motallebi and the authors have conducted the 
study. Mohammadreza Zamani: Data analysis and interpretation. Amir Mousavi: advised in particle bombardment. Daryoush Davoodi: advised in sugarcane tissue culture. Soheila Matroodi: has contributed in all aspects of the work. Zahra Moghaddassi-Jahromi: as lab and technical assistance.

\section{Financial Disclosure}

There is no conflict of interest between the authors.

\section{Funding/ Support}

This research was funded by National Institute of Genetic Engineering and Biotechnology (NIGEB).

\section{References}

1. Asano T, Tsudzuki T, Takahashi S, Shimada H, Kadowaki K. Complete nucleotide sequence of the sugarcane (Saccharum officinarum) chloroplast genome: a comparative analysis of four monocot chloroplast genomes. DNA Res. 2004;11(2):93-9

2. Hogarth D, Hogarth M, Allsopp P, Queensland. Bureau of Sugar Experiment Stations . Manual of Cane Growing. 2000.

3. Behera KK, Sahoo S. Rapid in vitro micropropagation of sugarcane (Saccharum officinarum L. cv-Nayana) through callus culture. Nature Sci. 2009;7(4):1-10

4. Merkle SA, Parrott WA, Williams EG, Bhojwani SS. Plant tissue culture: applications and limitations. In: Merkle SA, Parrott WA, Williams EG, Bhojwani SS, editors.Elsevier; 1990.

5. Parmessur Y, Aljanabi S, Saumtally S, Dookun-Saumtally A. Sugarcane yellow leaf virus and sugarcane yellows phytoplasma: elimination by tissue culture. Plant Pathol. 2002;51(5):561-566

6. Zale JM, Borchardt-Wier H, Kidwell KK, Steber CM. Callus Induction and Plant Regeneration from Mature Embryos of a Diverse Set of Wheat Genotypes. Plant Cell Tissue Organ Cult. 2004;76(3):277-81

7. Burner MD. Regeneration and phenotypic variability of plants cultured in vitro from mature sugarcane caryopses. J Am Soc Sugar Cane Technol. 1992;12:82-90

8. Gandonou C, Abrini J, Idaomar M, Skali SenhajiN. Response of sugarcane (Saccharum sp.) varieties to embryogenic callus induction and in vitro salt stress. Afr J Biotechnol. 2005;4(4):350-4

9. Desai NS, Suprasanna P, Bapat VA. Simple and reproducible protocol for direct somatic embryogenesis from cultured immature inflorescence segments of sugarcane (Saccharum spp.). Curr Sci. 2004;87(6):764-8

10. Naz S, Siddiqui A. Somatic embryogenesis and plantlet formation in different varieties of sugarcane (Sacchrum officinarum L.) HSF-243 and HSF-245. Sarhad J Agric. 2008;24(4):593-8

11. Malabadi RB, Mulgund GS, Nataraja K, Vijaya Kumar S. Induction of somatic embryogenesis in different varieties of sugarcane (Saccharam officinarum L.). Res Plant Biol. 2011;1(4):39-48

12. Frame BR, Zhang H, Cocciolone SM, Sidorenko LV, Dietrich CR, Pegg SE, et al. Production of transgenic maize from bombarded type II callus: Effect of gold particle size and callus morphology on transformation efficiency. In Vitro Cell Develop Biol Plant. 2000;36(1):21-29

13. Zhao H, Li M, Pei Y, Guo Y, Dong Y. Factors affecting wheat transformation efficiency by particle bombardment. Sichuan daxue xuebao. 2001;38(4):570-4

14. Carsono N, Yoshida T. Transient Expression of Green Fluorescent Protein in Rice Calluses : Optimization of Parameters for Helios Gene Gun Device. Plant Product Sci. 2008;11(1):88-95

15. Meng Y, Moscou MJ, Wise RP. Blufensin1 negatively impacts basal defense in response to barley powdery mildew. Plant Physiol. 2009;149(1):271-85

16. Mousavi M, Mousavi A, Habashi A, Arzani K. Optimization of physical and biological parameters for transient expression of uidA gene in embryogenic callus of date palm (Phoenix dactylifera L.) via particle bombardment. Afr J Biotechnol. 2009;8(16):3721-30

17. Bhore SJ, Shah FH. Genetic transformation of the american oil palm (Elaeis oleifera) immature zygotic embryos with antisense palmitoyl-acyl carrier protein thioesterase (PATE) gene. World Appl Sci J. 2012;16(3):362-9

18. Sanford JC, Smith FD, Russell JA. Optimizing the biolistic process for different biological applications. Methods Enzymol. 1993;217:483-509

19. Murashige T, Skoog F. A Revised Medium for Rapid Growth and Bio Assays with Tobacco Tissue Cultures. Physiol Plantarum. 1962;15(3):473-97

20. McElroy D, Zhang W, Cao J, Wu R. Isolation of an efficient actin promoter for use in rice transformation. Plant Cell. 1990;2(2):16371

21. Jefferson RA, Kavanagh TA, Bevan MW. GUS fusions: beta-glucuronidase as a sensitive and versatile gene fusion marker in higher plants. EMBO J.1987;6(13):3901-7

22. Joyner SP, SAS Institute. SAS/STAT guide for personal computers, Version 6 edition. 1985.

23. Basnayake SW, Moyle R, Birch RG. Embryogenic callus proliferation and regeneration conditions for genetic transformation of diverse sugarcane cultivars. Plant Cell Rep. 2011;30(3):439-48

24. Jackson MA, Anderson DJ, Birch RG. Comparison of Agrobacterium and particle bombardment using whole plasmid or minimal cassette for production of high-expressing, low-copy transgenic plants. Transgenic Res. 2013;22(1):143-51

25. Guirimand G, Burlat V, Oudin A, Lanoue A, St-Pierre B, Courdavault V. Optimization of the transient transformation of Catharanthus roseus cells by particle bombardment and its application to the subcellular localization of hydroxymethylbuteny 4-diphosphate synthase and geraniol 10-hydroxylase. Plant Cell Rep. 2009;28(8):1215-34

26. Battraw MJ, Hall TC. Histochemical analysis of CaMV 35S promoter-beta-glucuronidase gene expression in transgenic rice plants. Plant Mol Biol.1990;15(4):527-38

27. Park SH, Yi N, Kim YS, Jeong MH, Bang SW, Choi YD, et al. Analysis of five novel putative constitutive gene promoters in transgenic rice plants. J Exp Bot. 2010;61(9):2459-67

28. Petrillo CP, Carneiro NP, Purcino AAC, Carvalho CHS, Alves JD, Carneiro AA. Optimization of particle bombardment parameters for the genetic transformation of Brazilian maize inbred lines. Pesquisa Agropecuaria Brasileira. 2008;43(3):371-8

29. Lonsdale D, Onde S, Cuming A. Transient expression of exog enous DNA in intact, viable wheat embryos following particle bombardment. J Exp Bot. 1990;41(9):1161-5

30. Schöpke C, Taylor NJ, Cárcamo R, Beachy RN, Fauquet C. Optimization of parameters for particle bombardment of embryogenic suspension cultures of cassava (Manihot esculenta Crantz) using computer image analysis. Plant Cell Rep. 1997;16(8):526-30

31. Sreeramanan S, Maziah M, Abdullah MP, Sariah M, Xavier R, Nor Aini MF. Pysical and biological parameters affecting transient GUS and GFP expression in banana via particle bombardment. Asia Pacific J Biol Biotechnol. 2005;13(1):35-57

32. Parveez GA, Chowdhury MKU, Saleh NM. Physical parameters affecting transient GUS gene expression in oil palm (Elaeis guineensis Jacq.) using the biolistic device. Indus Crops Prod. 1997;6(1):41-50

33. Altpeter F, Vasil V, Srivastava V, Stöger E, Vasil IK. Accelerated production of transgenic wheat (Triticum aestivum L.) plants. Plant Cell Rep. 1996;16(1-2):12-7

34. Rasco-Gaunt S, Riley A, Barcelo P, Lazzeri PA. Analysis of particle bombardment parameters to optimise DNA delivery into wheat tissues. Plant Cell Rep.1999;19(2):118-27 